\title{
The Choice of Recycling Methods for Single-Polymer Polyester Composites
}

\author{
KATARZYNA GAWDZINSKA ${ }^{1}$, MARCIN NABIALEK ${ }^{2}$, ANDREI VICTOR SANDU3,4*, KATARZYNA BRYLL ${ }^{1}$ \\ ${ }^{1}$ Department of Shipbuilding Materials Engineering, Faculty of Marine Engineering, Maritime University of Szczecin, Willowa \\ 2-4, 71-650 Szczecin, Poland \\ ${ }^{2}$ Institute of Physics, Faculty of Production Engineering and Materials Technology, Czestochowa University of Technology, Armii \\ Krajowej 19, 42-200 Czestochowa, Poland
}

\begin{abstract}
This work has described the production of single-polymer composites by the film-stacking method. Two types of single-polymer composites with different mass fractions of the polyester reinforcement phase (10\% and 20\%) and the PETG matrix were investigated. The produced composites were subsequently recycled by injection moulding, pressing, and extrusion. Selected properties of the processed composites were determined: density, viscosity-average molecular weight, impact resistance, and tensile strength. The work done in this paper has demonstrated the benefits and drawbacks of each recycling method for these materials. The selected properties of single-polymer polyester composites and single-polymer polyester composites that were recycled by extrusion have also been compared.
\end{abstract}

Keywords: single-polymer composites, polyesters, film-stacking method, recycling, extrusion, injection moulding, pressing

Polymer composite materials are the most promising and evolving group of modern construction materials, which are very popular in the domains of science, technology, industry, and business due to their attractive functional properties [1-2]. The widespread use of polymeric composites in various industries (fig. 1) necessitates that they be continuously modified, their properties be investigated, and the materials be recycled.

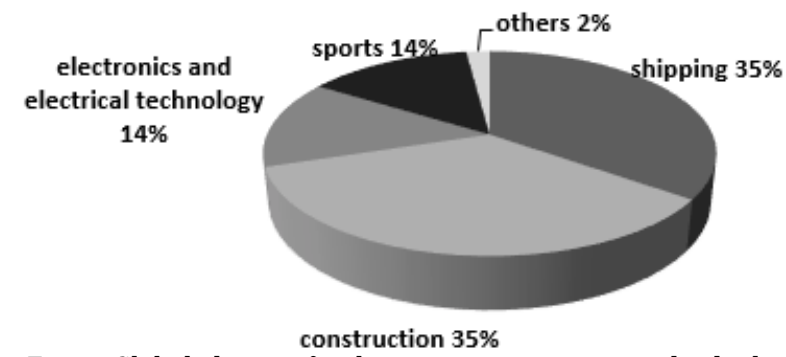

Fig. 1. Global shares of polymeric composites in individual industries [3-4]

The issue of polymer composite waste management has not yet been solved [3-4]. The problem is increasing due to gradual decommissioning of aircraft, watercraft, and wind turbine propellers that are made of laminates and so on. One solution to this problem is recycling. Recycling of polymeric materials is one of the most important waste management issues. The total quantity of this waste has more than doubled over the last ten years (especially in urban clusters). The choice of waste management method, i.e. a specific recycling method, depends on the so-called external and internal factors. The internal factors are the properties of the waste and the processing capability. External factors include the provisions of applicable laws and market needs [4-5].

The term recycling refers to a recovery operation, as part of which waste materials are reprocessed to make products, materials, or substances used for the original purpose or for other purposes $[4,6-8]$. In this case, the recovery is understood as actions which do not pose a risk to human health and life or the environment, and which involve the use of waste in whole or in part. Recycling can be divided into three types, i.e. energy recovery, material recycling, or chemical recycling. Energy recovery means the partial recovery of the energy necessary to manufacture the product. Depending on the type of waste and the technology applied in its production, it can be used to obtain gaseous, liquid, or solid energy sources. Material recycling means the physical or chemical reprocessing of collected and sorted waste into a use-value article or product

By contrast, chemical recycling is the recovery of substrates used to manufacture a given article. It allows the repeated application of raw materials for the production of full-value materials, and the resulting waste (heavy or light ends of petroleum) may be used as an additive to fuels or lubricants [3-4, 9-11]. In the case of chemical recycling, it should be borne in mind that the use of complex apparatus, systems, varying temperature, high pressure, and specialised equipment significantly increases the cost of the process and limits the use of this type of recycling. On the other hand, during the material recycling, the product's intended use is different from that of the original product (with lower requirements for final products).

A suitable choice of additives or substrates allows for highly efficient processing of recyclable materials of good quality. This type of processing is technologically simple when itconcerns a material with a homogeneous chemical structure, and very complicated when it comes to composite materials. Therefore, it is very important to constantly search for and identify the potential for recycling polymers, especially polymeric composites, as, according to the Directive 2008/98/EC of the European Parliament and the Council of 19 November 2008 on waste [12], this process is necessary and indispensable. The process of recycling polymers and polymeric composites is a very difficult and costly process [3-4, 13-24].

In principle, the material recycling is carried out in many stages (segregation, shredding, chemical or mechanical purification combined with drying the elements, forming, and manufacture of the final product), which significantly affects its cost. Currently, most of the polymer composite waste is carried to landfills or municipal incinerators. The storage of composite waste is prohibited in Germany and is subject to additional taxes in Sweden. It is likely that in 
the coming years such restrictions will be adopted by other European Union countries due to stricter environmental regulations. Restrictions are also to be imposed on companies producing composites, in order to introduce other methods of managing composite waste [4, 13-16].

Incineration is the second-most-popular method of recycling (use of waste as recyclable materials - energy recycling) of polymeric composites, including e.g. yacht hulls, and propellers of wind turbines. Typical composites in these applications are polyester or epoxy matrix composites with glass fibre reinforcement, with mass fraction of about $50-60 \%$. However, as a result of incineration, the glass ends up in the slag, which contains heavy metals, and must therefore be stored in safe pits and landfill sites in order to not pollute the natural environment [4, 14]. In addition, following the incineration process the fibre remains which can be reused. However, the recycled fibre-reinforced composite exhibits mechanical strength properties that are at least $50 \%$ lower than that of the primary material $[4,13-17]$.

Energy recovery is not economically viable due to the relatively low calorific values of resins, including polyester (calorific value of $25-30 \mathrm{MJ} / \mathrm{kg}$ ). In addition, too much ash remains and itmust be processed or disposed of later. Toxic gases (methane, ethane, ethylene, ethylbenzene, acetylene, carbon monoxide, etc.) are also emitted during incineration of laminates. Therefore, it is more appropriate to recycle these materials chemically by solvolysis (lyolysis), which causes a slight reduction (only $50 \%$ ) in the strength of the recovered glass fibre [13-17]. Another chemical recycling method is pyrolysis or degradation in various solvents (esters, ketones, alkalis, and concentrated oxidative acids) [5]. In this way, raw materials for further processing can be obtained. However, these are expensive methods [5,13-15].

Therefore, material recycling is the best solution to the problem of polymer composite waste, because it does not require a large investment outlay. The waste is shredded to obtain fibres or fillers, which are then added to the resulting products. This does notforce the production plants to make drastic changes to production technology [3-5, 911]. Recycled materials should be cheap and have good functional properties, and their production should be environmentally friendly. Continued progress in the recycling of composite materials, which were recently considered inappropriate for reuse, encourages the search for new and better solutions and ways to manage this waste. This is also the reason for the search for new materials or combinations of fibre and matrix to replace traditional composites.

An interesting innovation that facilitates both material and energy recycling is the suggestion to use thermoplastic fibre reinforcement, made of the same material as the matrix, to produce a so-called single polymer composite. single-polymer composites (SPC) means composites made of fibre and matrix, produced from the same polymeric, or very similar, material, where the components may differ from each other in molecular weight, density, or branching degree [25-28]. These thermoplastic composites do respond to the need for reinforced materials with favourable mechanical properties. They also have a great advantage, namely they can be easily and completely recycled after use.

In recent years, single-polymer composites have increasingly been the subject of scientific research. In the literature, there is research into this type of materials and there are descriptive examples of single-polymer polyethylene or polypropylene composites. However, the idea of single-polymer composites is also being implemented for other polymeric materials, i.e. poly(methyl methacrylate) or polyester. In industrial processes for single-polymer composites, the following manufacturing methods prevail: infusion of polymeric solutions or powders, pressing of fibres or polymer tapes, pressing of films and reinforcement phases, and injection moulding.

\section{Methods of Producing Single-Polymer Composites with Polyester Matrix}

The literature review showed that research has been conducted into composites based on fibres with high crystallinity and amorphous PET films. The processing range was expanded using materials with a high disparity in their melting temperatures. (Donggang Yao et al. [29]). The composite was manufactured at $180^{\circ} \mathrm{C}$, for $90 \mathrm{~s}$, at a pressure of approximately $0.7 \mathrm{MPa}$. In addition, the study also showed a correlation between the heat up rate and the quality of the fibre-matrix bond. It was found that as the heat up rate decreased, the properties at the matrixfibre interface significantly deteriorated.

Hine and Ward [30] described how to produce composite sheets by hot compaction of PET fibres. The examination of various processing parameters has shown that the most important of them are temperature and compaction time. The molecular weight determination, using the viscosity limit, showed that hydrolytic degradation occurred rapidlyat the temperatures required for effective compaction, leading to the fragility of the materials obtained and the need to increase the compaction time. The optimal production time was about 2 minutes, which caused the melting of an amount of material sufficient for the consolidation of the composite, with a slight change in the molecular weight. The authors used various research techniques, including mechanical testing, differential scanning calorimetry (DSC), and scanning electron microscopy (SEM) to examine the mechanical and thermal properties and the morphology of the sheets obtained. The results of these measurements confirmed that the properties of both components, i.e. the original orientation of the fibre and the matrix recrystallisation, have been combined in the composite.

Zhang etal. [31] presented the production of the all-PET composite by the film-stacking method, prepared by laying PET tapes and co-PET film. The processing range has been established in a number of tests (including DSC tests) for tapes and foils. The tensile strength of PET tapes, Co-PET, and SPC-PET films was observed and compared with the commercially available co-extruded PP tape. The effect of the process temperature and pressure on the tensile strength was also determined. The aim of this research was to optimize the processing parameters while maintaining good adhesion at the phase boundary.

Rojanapitayakorn et al. [32] produced a single-polymer composite from PET by compacting stacked PET fibres under pressure, at a temperature slightly below the melting temperature of the composite's components. The research has shown an increase in the crystallinity of fibre bundles that originally were white, and a parallel increase in their translucency following the forming process. Crystalline orientation was investigated using the Hermans orientation parameter from WAXD data. No significant loss of orientation of the crystal phase was recorded during pressing. The mechanical characteristics of the material indicated that as the compaction temperature increased from 255 to $259^{\circ} \mathrm{C}$, the modulus of elasticity $(9.4-8.1 \mathrm{GPa})$ was reduced and the tensile strength increased at the same time. This change was accompanied by a loss of optical transparency and a change in the arrangement of 
the amorphous phase, as found in the SEM tests. The mechanical properties of SPC-PET were influenced by the orientation of the amorphous phase, rather than the crystalline phase. The Charpyimpact test (performed with a special hammer) showed a drop in the notch impact strength as the process temperature increased.

Duhovic et al. [33] using the experience gained in the development of nanofibre-reinforced polymeric composites, attempted to produce PET/PET-nanofibre composites. For this purpose, PET nanofibre was placed between the PET films, with a lower melting point than the fibre, to produce the composite by pressing at a temperature of $120^{\circ} \mathrm{C}$. The obtained composites showed an improvement in tensile strength and an increase in the modulus of elasticity compared to the matrix materials.

J. C. Chen et al. [34] described the production of poly(ethylene terephthalate) (PET) composite using a modified film pressing technique. The components making up the product were the high-strength PET yarn and the matrix: a biodegradable polyester material with a low melting point. The difference between the melting points of the two components was approximately $56^{\circ} \mathrm{C}$. The produced sheets were tested at different temperatures $\left(215,225\right.$, and $\left.235^{\circ} \mathrm{C}\right)$ with both a constant process time $(6.5 \mathrm{~min}$ ) and with varying process times ( 3.5 and $10 \mathrm{~min}$ ) but at a constant process temperature of $225^{\circ} \mathrm{C}$. Analysing the results of the tests, significant improvements in the mechanical properties of obtained composites, compared to the matrix material, were observed. Therefore, the basic methods of producing single-polymer polyester composites include:

\section{Infusion of polymeric solutions or powders}

This is a variant of infusion, the conventional method of production of polymeric composites. It consists of saturation of the reinforcement with plasticized polymeric material, which is the SPC matrix [30]. This process is characterized by low efficiency, because it takes a long time for the matrix reinforcement to become saturated with the liquid polymer. One of the basic limitations of the infusion method is the possibility of partial thermal degradation of the reinforcing phase and the subsequent deterioration of the mechanical properties of the composite.

\section{Hot compaction of polymeric fibres or tapes}

The hot compaction of polymeric fibres or tapes consists of production of boards and sheets by heating up a bundle of highly oriented parallel fibres or polymer tapes and then pressing them together and cooling them down. The matrix material is the outer molten layer made of the fibre or tape, and the non-molten fibre core will be the reinforcement. The difference between the minimum compaction temperature and the melting temperature of the fibre/tape is usually around $5^{\circ} \mathrm{C}$, which makes it difficult to process the material efficiently [30]. Too high a process temperature may resultin the deterioration of the functional properties. One of the greatest advantages of this production method is that it maintains the continuity of the material at the molecular level, which results in a strong bond between the matrix and the reinforcement [27].

\section{Injection moulding}

Injection moulding is one of the most important processing methods for thermoplastics, but it is an uncommon method for production of SPC. The reasons for this are mainly technological limitations resulting from degradation and destruction of the reinforcement phase during transport in the plasticizing system, as well as the necessity to prepare the composite intermediate in granulate form [26-28].

\section{Film-stacking}

One of the oldest methods of producing SPCS is the film-stacking method invented by Capiati N.J. and Porter R.S. [26]. It involves positioning the reinforcing phase between the two films (matrix) made of a polymer identical to the reinforcing component, but with a lower melting point, and then hot compaction of the so prepared material in conditions which allow plasticizing of the film, without even partial melting of the reinforcing phase. The compaction pressure must be sufficiently high to allow the molten polymer matrix to completely fill the free space that exists between the polyester fibres. In addition, in order to avoid deterioration of the reinforcing fibre properties, very short heating and cooling times should be used [26].

From the above considerations it follows that it is possible to produce single-polymer polyester composite materials with different forms of the reinforcing phase and by different techniques, and thus change the properties of the products. The objective of this paper was to conduct research associated with choosing the best method of processing these materials.

\section{Choosing a Recycling Method for Single-Polymer Polyester Composites}

The aim of this paper was to produce single-polymer composite materials by the film-stacking method and subsequently recycling them by pressing, injection moulding, and extrusion in order to determine the most effective method of reprocessing these materials (fig. 2.). The purpose of this process was to obtain a product in a form of film with a homogeneous structure and substratelike properties, which at a later stage can be used for the fabrication of certain products.

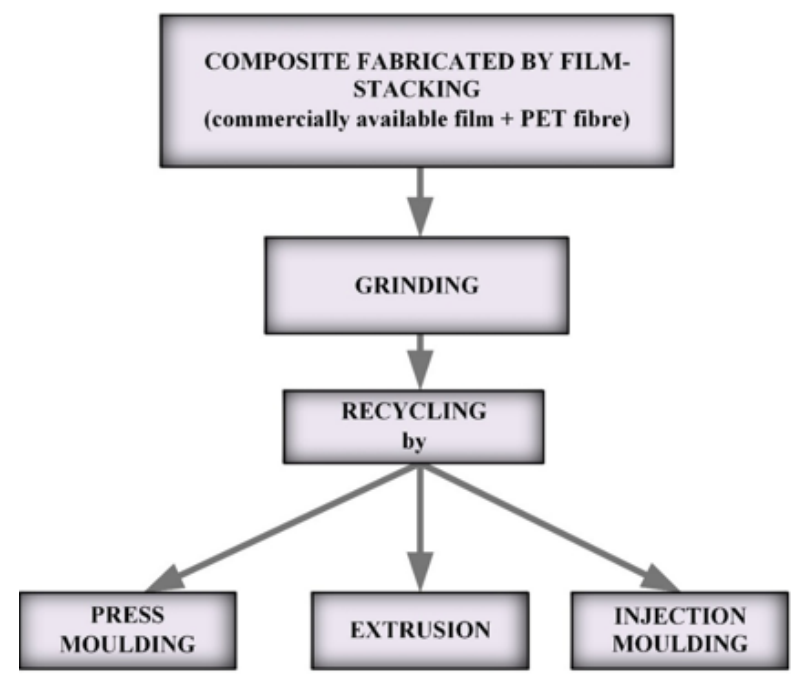

Fig. 2. The choices of recycling method for single-polymer polyester composites

The following constituents were used for the fabrication of single-polymer polyester composites:

-reinforcement made of high-strength poly(ethylene terephthalate) [PET] fibres from TORLEN SPÓ EKA Z O.O. The fibre was polyester silk (pre-oriented), which is an input raw material for the production of silk spun from the semimatt polymer (186/24 [dtex/f]). Its strength is defined as elongation at break 126\% $19 \mathrm{cN} /$ tex, and purchased in spools with a length of $205 \mathrm{~mm}$. In the research, the reinforcing phase was formed by roving (into arranged filament fibres, fig. 3). 
$20 \mathrm{~mm}$

Fig. 3. The microstructure of the phase reinforcing the filament fibres in the polyester matrix

-the matrix in the form of a $0.5 \mathrm{~mm}$ thick commercial film made of glycol-modified poly(ethylene terephthalate) [PETG] from VIVAK. The commercial film was supplied in $2050 \times 1000 \times 0.5 \mathrm{~mm}$ sheets. The film was prepared by cutting it with a ream cutter to a size corresponding to the dimensions of the mould cavity and degreasing the material.

The reinforcement and matrix materials were prepared in laboratory conditions at ambient temperature. Ten kilograms of input products were used in this paper.

The composites were made by the film-stacking method (process parameters are shown in table 1). Single-polymer polyester composites with a reinforcement phase mass fraction of $10 \%$ and $20 \%$ and PETG matrix were recycled using the methods presented in figure 2 (injection, extrusion, pressing). The markings of the examined materials are presented in table 2.

\section{Recycling of Single-Polymer Polyester Composites by Pressing}

Pressing is a method of processing that involves cyclic introduction of the material into a closable mould cavity, plasticizing, melting, and then solidification of the material. Finally, the finished object, called in this case the pressmoulded piece, is removed from the cavity. The pressing process takes place in or without presses, but always occurs with the use of a tool, which is a press mould with a mould cavity. The pressing process can be divided, according to the way in which the material is delivered to the mould cavities, into compression moulding and transfer moulding. The parameters that characterize press moulding are pressure, temperature, and duration of the process [25-30].

Compression moulding was used in the recycling process. Regranulate was evenly placed in the mould cavity and then pressed at temperatures above the softening point of the fibre. The process parameters are shown in Table 3. The material was cooled down in the press using special plates with a water-cooling system. The resulting pressmoulded piece was a thinfilm, from which sections corresponding to the dimensions of the mould cavity were cut out on the ream cutter.

An example of a moulded piece is shown in figure 4.

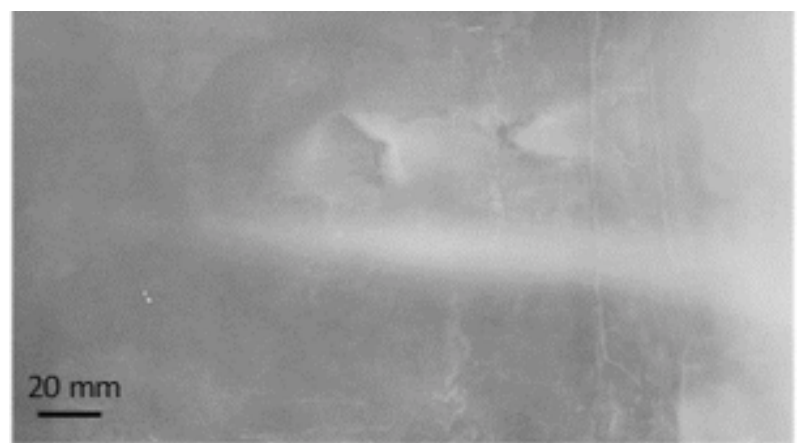

Fig. 4. An example of a moulded piece from recycling (press moulding)

Recycling of Single-Polymer Polyester Composites by Injection Processing

Injection processing consists of cyclic plasticizing, and then melting the material in the plasticizing system, pressing it into a closed mould cavity, solidification, and then removal of the object, called an injection-moulded piece, from the cavity (fig. 5). The injection moulding process is carried out in injection moulding machines,

Table 1

FILM-STACKING METHOD PROCESS PARAMETERS

\begin{tabular}{|c|c|c|c|c|}
\hline PARAMETER & DRYING & PI & & COOLING \\
\hline TEMPERATURE & $60^{\circ} \mathrm{C}$ & $234-237^{\circ} \mathrm{C}$ & $234-237^{\circ} \mathrm{C}$ & to room temperature \\
\hline TIME & more than $6 \mathrm{~h}$ & $15-60 \mathrm{~s}$ & $15-60 \mathrm{~s}$ & $200-360 \mathrm{~s}$ \\
\hline PRESSURE & in vacuum & $15-20 \mathrm{bar}$ & $20-25$ bar & - \\
\hline
\end{tabular}

\begin{tabular}{|c|c|c|}
\hline Marking & Recycling method & $\begin{array}{l}\text { The reinforcement mass fraction } \\
\text { single-polymer composite } \\
\text { SUBSTRATE }\end{array}$ \\
\hline PR05 & pressing & mass fraction of $10 \%$ PET in the PET \\
\hline PR15 & pressing & mass fraction of $20 \%$ PET in the PET \\
\hline WT05 & injection moulding & mass fraction of $10 \%$ PET in the PET \\
\hline WT15 & injection moulding & mass fraction of $20 \% \mathrm{PET}$ in the PET \\
\hline WYO5 & extrusion & mass fraction of $10 \%$ PET in the PET \\
\hline WY15 & extrusion & mass fraction of $20 \% \mathrm{PET}$ in the PET \\
\hline PARAMETER & PRESS MOULDING & COOLING DOWN \\
\hline $\begin{array}{c}\text { TEMPERATURE } \\
{\left[{ }^{\circ} \mathrm{C}\right]}\end{array}$ & $265-268$ & to the ambient temperature \\
\hline TIME [s] & 300 & $200 \mathrm{~s}$ \\
\hline PRESSURE [MPa] & 1.5 & - \\
\hline OTHER & press-moulded in the air & press-moulded in the air \\
\hline
\end{tabular}

Table 2

MARKINGS OF MATERIALS USED IN THE PAPER 


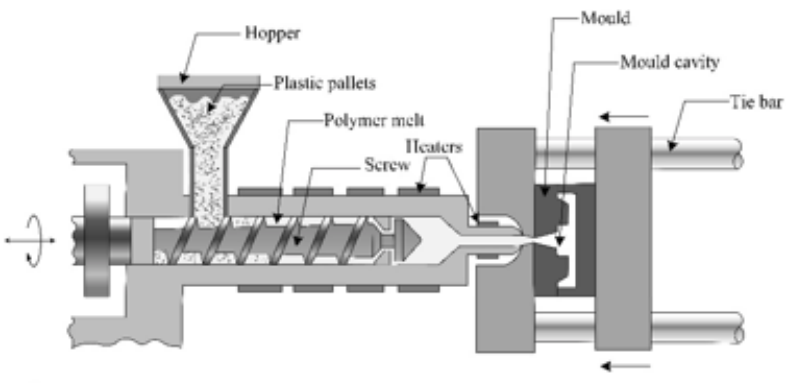

Stage I

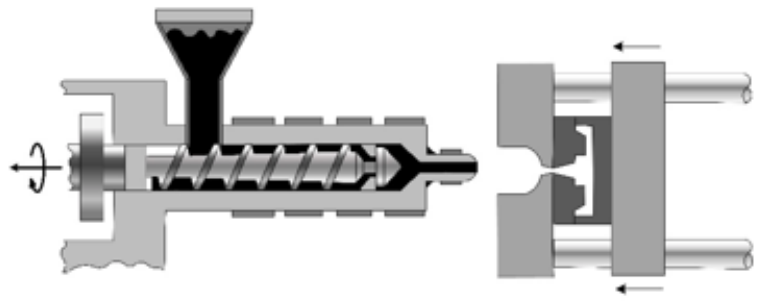

Stage II
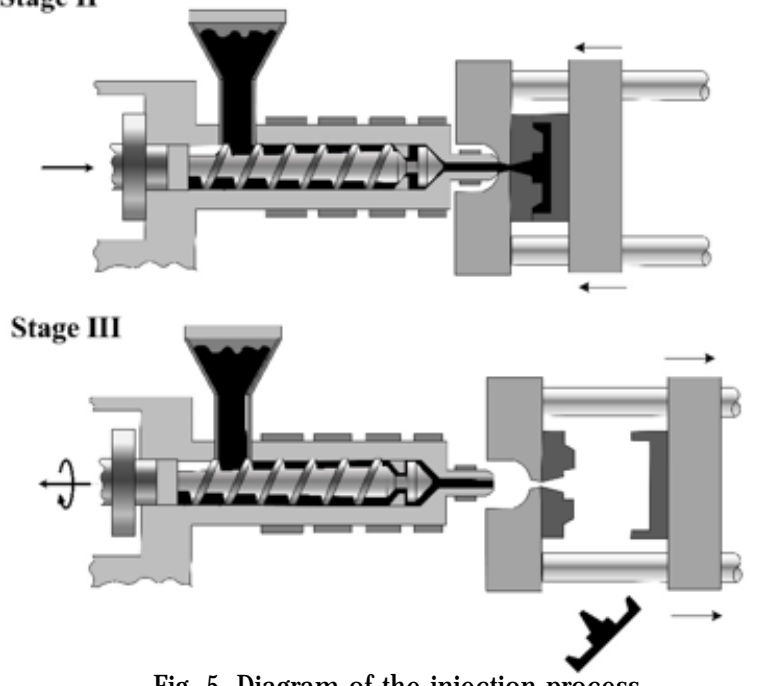

Fig. 5. Diagram of the injection process

Stage I -closing both halves of the mould and arrival of the plasticizing system, Stage II -injection of the material into the mould, Stage III opening both halves of the mould, removal of a moulded piece, departure of the plasticizing system, taking a new dose of the material (granulate)

\begin{tabular}{|c|c|c|c|c|}
\hline Material & $\begin{array}{c}\text { Injection } \\
\text { pressure } \\
{[\mathrm{MPa}]}\end{array}$ & $\begin{array}{c}\text { Processing temperature } \\
{\left[{ }^{\circ} \mathbf{C}\right]}\end{array}$ & $\begin{array}{c}\text { Clamping } \\
\text { time } \\
{[\mathrm{s}]}\end{array}$ & $\begin{array}{c}\text { Cooling } \\
\text { down time } \\
{[\mathrm{s}]}\end{array}$ \\
\hline $\begin{array}{c}\text { Composite with reinforcement } \\
\text { mass fraction of } \mathbf{1 0} \%\end{array}$ & 75 & 250 & 8 & 10 \\
\hline $\begin{array}{c}\text { Composite with reinforcement } \\
\text { mass fraction of 20\% }\end{array}$ & 75 & 260 & 8 & 10 \\
\hline
\end{tabular}

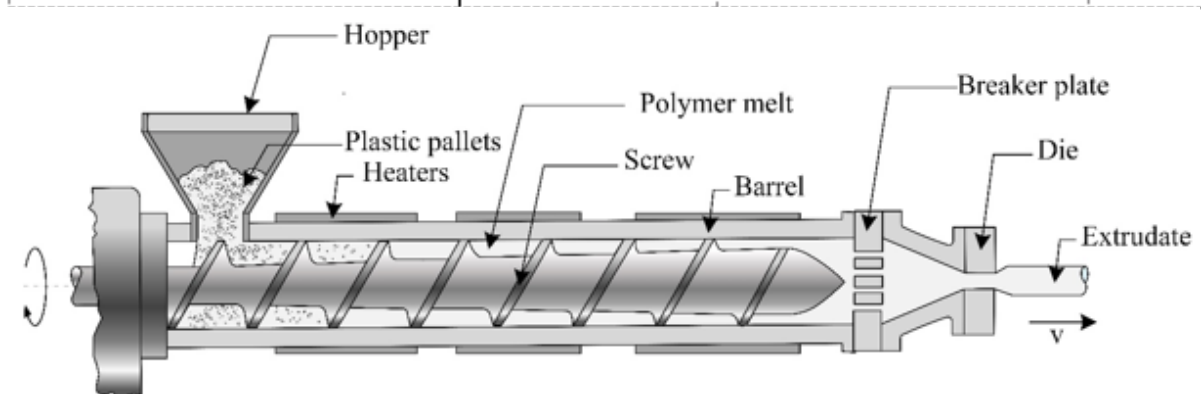

\begin{tabular}{|c|c|c|c|c|}
\hline Material & $\begin{array}{c}\text { Angular speed of } \\
\text { the screw } \\
{[\mathbf{r p m}]}\end{array}$ & $\begin{array}{c}\text { Processing } \\
\text { temperature } \\
{\left[{ }^{\circ} \mathrm{C}\right]}\end{array}$ & $\begin{array}{c}\text { Processing } \\
\text { temperature } \\
{\left[{ }^{\circ} \mathrm{C}\right]}\end{array}$ & $\begin{array}{c}\text { Head } \\
\text { temperature } \\
{\left[{ }^{\circ} \mathrm{C}\right]}\end{array}$ \\
\hline $\begin{array}{c}\text { Composite with } \\
\text { reinforcement mass } \\
\text { fraction of 10\% }\end{array}$ & 198 & 240 & 250 & 250 \\
\hline $\begin{array}{c}\text { Composite with } \\
\text { reinforcement mass } \\
\text { fraction of 20\% }\end{array}$ & 198 & 240 & 260 & 260 \\
\hline
\end{tabular}

Fig. 6. Schematic diagram of classical extrusion

Table 5

PARAMETERS OF

RECYCLING BY

EXTRUSION PROCESSING 


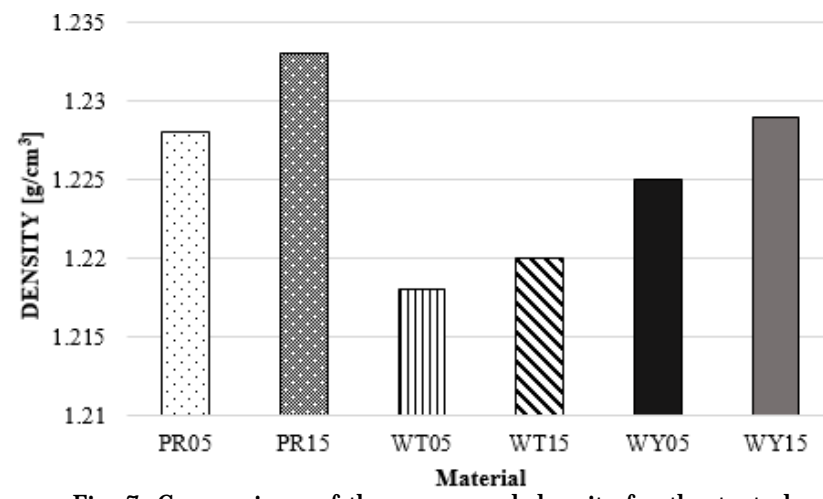

Fig. 7. Comparison of the measured density for the tested materials

\section{Research Findings and Overview}

In order to determine the most effective method of processing these materials, their basic physical and chemical properties have been determined.

The density of the composites was determined by the hydrostatic method according to the PN-EN ISO 11831:2013-06 standard. The test was carried out at $23^{\circ} \mathrm{C}$. The Charpy impact strength was determined in accordance with the PN-EN ISO 179-1:2010 standard. It was carried out for samples without the notch in the form of a type 2 bar. The viscosity-average molecular weight was determined in order to ascertain the degradation of the material that occurred during processing. 7-9.

The results of the measurements are shown in figures

From the analysis of the results of the density measurement it follows that the greater the fraction of the reinforcement phase in the substrate, the higher the density.

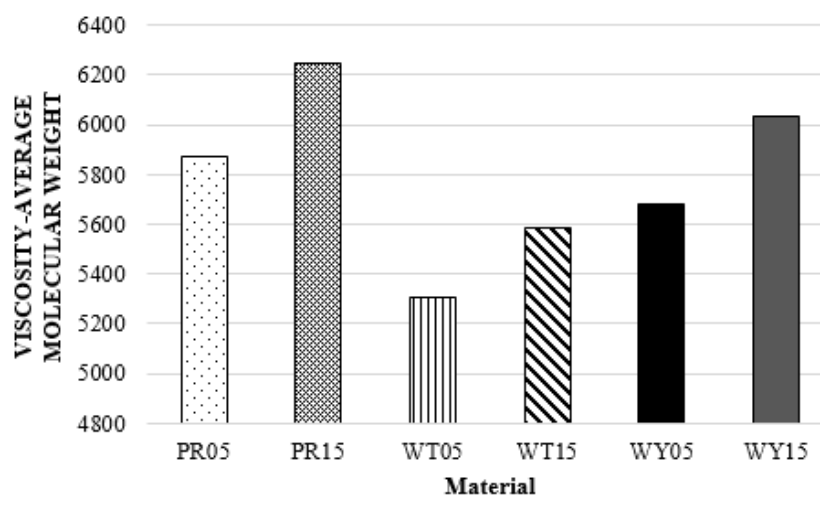

Fig. 8. Viscosity-average molecular weight of the tested materials

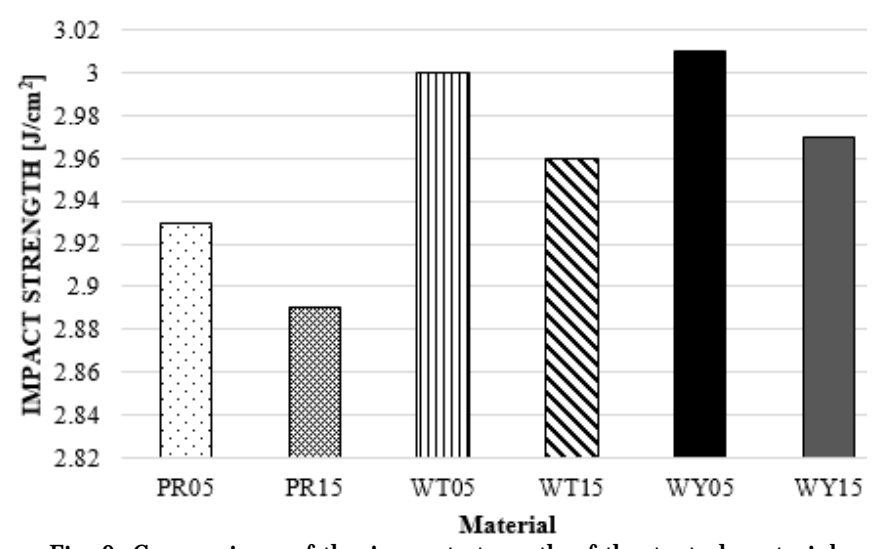

Fig. 9. Comparison of the impact strength of the tested materials

The material with the highest density was obtained by press moulding and the lowest by injection moulding. This is most likely related to the degradation of the macromolecules, which was confirmed by the results of the determination of the viscosity-average molecular weight. The determination of the viscosity-average molecular weight was achieved for the recyclable film obtained by the various technological processes. The results are shown in figure 8.

The decrease in the molecular weight of the tested materials, which were subjected to processing, may be influenced by temperature, pressure, humidity, and time. From the analysis of the obtained results, it can be concluded that the lowest degradation of the macromolecules, as a result of the processing, was found in the press-moulded film and the highest value was found in the injected material. Shear forces that arise during plasticization and high pressure during the injection process are the cause of this. Figure 9 shows the impact strength testresults of single-polymer polyester composites that were recycled by the different methods.

The analysis of the results of the impact strength test showed that it was not only degradation of the macromolecules that had an impact on the mechanical properties of the polymer. Despite the least amount of degradation of the press-moulded film, it exhibited the lowest impact strength among the tested materials. This was caused by the inhomogeneity of the resulting structure [26-30].

Table 6

SUMMARY OF THE DISADVANTAGES AND ADVANTAGES OF PETG MATRIX RECYCLING METHODS

\begin{tabular}{|c|c|c|}
\hline Recycling method & Disadvantages & Advantages \\
\hline Press moulding & $\begin{array}{l}\text { - cyclic process, } \\
\text { - material quantity limited by mould } \\
\text { cavity volume } \\
\text { - high cost of process equipment } \\
\text { - long preparation time and high } \\
\text { financial outlays related to the } \\
\text { implementation of a new product for } \\
\text { production } \\
\text { - no homogenisation of the material } \\
\text { - formation of a fragile crystalline phase } \\
\text { - partial loss of the material's } \\
\text { transparency } \\
\text { - uneven distribution of properties on } \\
\text { the surface of the finished product }\end{array}$ & $\begin{array}{l}\text { - feasibility of three recycling stages } \\
\text { (plasticization, forming, cooling down) on } \\
\text { a single machine } \\
\text { - possibility of skipping the shredding } \\
\text { process if the composite fits on the work } \\
\text { surface } \\
\text { - with the use of a mould, it is possible to } \\
\text { obtain the finished product without the need } \\
\text { for finishing } \\
\text { - possibility to fully automate and } \\
\text { computerize the process } \\
\text { - low/average degradation of the material } \\
\text { during the process }\end{array}$ \\
\hline
\end{tabular}




\begin{tabular}{|c|c|c|}
\hline Extrusion moulding & $\begin{array}{l}\text { - cyclic process } \\
\text { - partial loss of the material's } \\
\text { transparency } \\
\text { - the need to implement another process } \\
\text { to obtain thin films } \\
\text { - high cost of machinery and moulds }\end{array}$ & $\begin{array}{l}\text { - good homogenisation of materials } \\
\text { - high quality and reproducibility of } \\
\text { properties } \\
\text { - possibility to fully automate and } \\
\text { computerize the process } \\
\text { - high degradation of the material during } \\
\text { the process }\end{array}$ \\
\hline Injection processing & $\begin{array}{l}\text { - continuous process } \\
\text { transparency }\end{array}$ & $\begin{array}{l}\text { - good homogenisation of materials } \\
\text { - possibility of cooling down on rollers or } \\
\text { forming the film by blow moulding } \\
\text { - possibility to fully automate and } \\
\text { computerize the process } \\
\text { - low degradation of the material during the } \\
\text { process }\end{array}$ \\
\hline
\end{tabular}

Continuated table 6
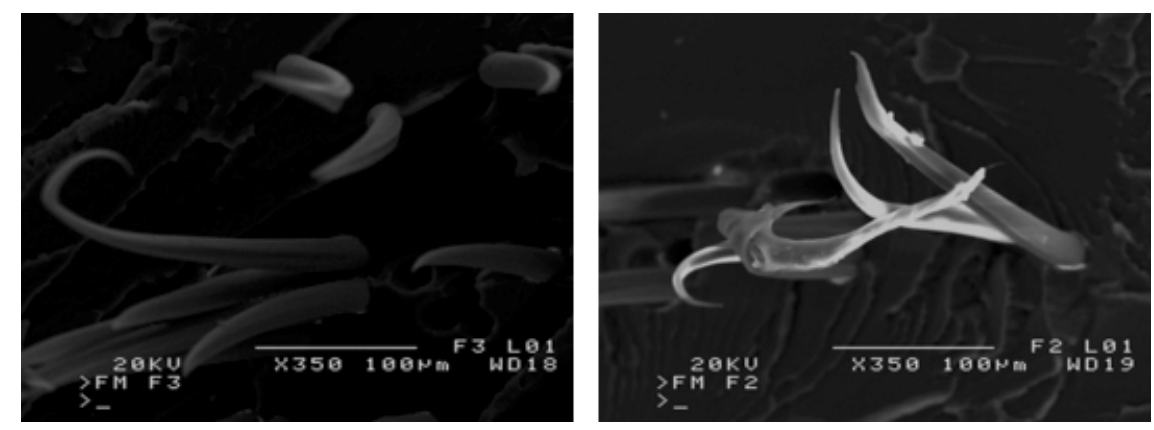

Fig. 10. Microstructure of a single-polymeric polyester composite (SEM) -a turning point after the tensile strength test: (a) original composite; (b) extruded film composite (WY05).

Table 7

COMPARISON OF SELECTED PROPERTIES OF A SINGLE-POLYMER POLYESTER COMPOSITE AND A SINGLE-POLYMER POLYESTER COMPOSITE RECYCLED BY EXTRUSION MOULDING.

\begin{tabular}{|c|c|c|c|c|c|}
\hline Material & $\begin{array}{l}\text { Mass fraction of the } \\
\text { reinforcement phase }\end{array}$ & Density $\left[\mathrm{g} / \mathrm{cm}^{3}\right]$ & $\begin{array}{c}\text { Ultimate } \\
\text { tensile strength } \\
\text { [MPa] }\end{array}$ & $\begin{array}{c}\text { Impact } \\
\text { strength } \\
{\left[\mathrm{J} / \mathrm{cm}^{2}\right]}\end{array}$ & $\begin{array}{c}\text { Bending } \\
\text { strength } \\
\text { [MPa] }\end{array}$ \\
\hline Original & $10 \%$ & 1.232 & 59.8 & 4.98 & 93.8 \\
\hline Recycled & $10 \%$ & 1.244 & 58 & 4.57 & 92 \\
\hline
\end{tabular}

\section{Conclusions}

As a result of the work carried out into the recycling of single-polymer polyester composites, it was found that each of the selected methods for the production of SPCS (injection, press moulding, and extrusion) can be used for the processing of these materials while maintaining appropriate process parameters. A chart of the advantages and disadvantages of these methods has been developed and presented in table 6.

It was found that the optimal method of recycling is extrusion and composites processed in this way were characterized by good quality (fig. 10), stable functional parameters, and were the ones most similar (in comparison with the methods of processing by injection, pressing, and injection moulding) to the original composites (table 7).

\section{References}

1.JAKUBAS A., GEBARA P., SEME S., GNATOWSKI A., CHWASTEK K., Acta Phys. Pol. A, 2017, 5, 1289.

2.GEBARA, P., PAWLIK, P., J. Magn. Magn. Mater. 2017, 442, 145-151. 3.BLÊEZKI, A., GORYCY, K., URBANIAK, M., Polimery, 57, no. 9, 2012, p. 620.

4.BLEDZKI, A. K., TARTAKOWSKI, Z. (editors), Recycling and recovery of polymer materials materials-technologies-utilization; University Publisher of West Pomeranian University of Technology in Szczecin, 2010.
5.HEDLUND-ASTROM, A., LUTTROPP, C., REINHOLDSSON, P., Environmental Friendly Recycling Of Frp-sandwicH Ship Hulls: Recycling of Ships \& Other Marine Structures, London, UK, Royal Institution of Naval Architects 2005.

6.ASSOCIATES, E. G., Marine Composites. Maryland: Annapolis, 1999. 7.BRENT STRONG, A., Fundamentals of Composite Manufacturing: Materials, Method, and Applications. Society of Manufacturing Engineers, Michigan, 1989.

8.DVORAK, R, KOSIOR, E., HOPEWELL, J., Philosophical transactions of the Royal Society, 364, 1626, 2009, p. 2115.

9.CHYBOWSKI L., ZOLKIEWSKI S., Advances in Intelligent Systems and Computing, 354, 2015, p. 333

10.LAVEE, D., Environmental Management, 40, 6, 2007, p. 926.

11.GRZEBIENIAK R., CHYBOWSKI L., Scientific Journals of the Maritime University of Szczecin, 77, no. 5, 2005, p. 247.

12.*** Directive of the European Parliament and of the Council 2008/ 98 / EC of 19.11.2008 on waste, Official J ournal of the European Union, No. $L 312$ dated November 22, 2008

13.BARCZEWSKI, M., MATYKIEWICZ, D., ANDRZEJ EWSKI, J., SKORCZEWSKA, K., J Adv Res., 7, no. 3, 2016, p. 373.

14.AKESSON, D., FOLTYNOWICZ, Z., CHRISTEEN, J., SKRIFVARS, M., Polimery, 58, no. 7, 2013, p. 582.

15.ASMATULU, E., TW OMEY, J., OVERCASH, M., J ournal of Composite Materials, 48, no. 5, 2014, p. 1.

16.THOMASON, J., JENKINS, P., YANG, L.; Fibers, 4, 18; doi:10.3390/ fib4020018.

17.J ASTRZEBSKA, M., Composites Theory and Practice, 12, no. 3, 2012, p. 151. 
18.NEMES, O., Studia Universitatis Babes-Bolyai Chemia, 52, no. 4, 2007, p. 175.

19.PLATON, M.A.,STEF, M., POPA, C., TIUC, A.E., NEMES, O., IOP Conference Series-Materials Science and Engineering, 374, 2018, UNSP 012065.

20.TIUC, A.E., NEMES, O., PERHAITA, I., VERMESAN, H., GABOR, T., DAN, V., Studia Universitatis Babes-Bolyai Chemia, 60, no. 2, 2015, p. 169.

21.BUZEA, C.G., BEJINARIU, C., BORIS, C., VIZUREANU, P., AGOP, M., International J ournal of Nonlinear Sciences And Numerical Simulation, 10, no. 11-12, 2009, p. 1399.

22.IOANNOU, P.D., NICA, P., PAUN, V., VIZUREANU, P., AGOP, M., Physica Scripta, 78, no. 6, 2008, Article Number: 065101

23.VIZUREANU, P., Environmental Engineering And Management Journal, 8, no. 2, 2009, p. 301

24.ACHITEI, D., GALUSCA, D.G., VIZUREANU, P., CARABET, R., CIMPOESU, N., Metalurgia International, 14, 2009, p. 45

25.GUCMA, M., BRYLL, K., GAWDZINSKA, K., PRZETAKIEWICZ, W. PIESOWICZ, E.; Scientific J ournals of the Maritime University of Szczecin, 44, no. 116, 2015, p. 14.

26.CAPIATI, N.J ., PORTER, R.S; J. Mater. Sci., 10, 1975, p. 1671.

27.KARGER-KOCSIS, J., BARANY, T., Composites Science and Technology, 92, 2014, p. 77.
28.KMETTY, A., BARANY, T., KARGER-KOCSIS, J., Progress in Polymer Science, 35, 2010, p. 1288.

29.YAO, D., LI R.H., NAGARAJ AN, P. Polym Eng Sci 2006;46(9):1223-30 30.HINE, P.J, WARD, I.M. J Appl Polym Sci, 91, 2004, p. 2223.

31.ZHANG, J .M., REYNOLDS, C.T., PEIJ S, T. Compos PartA, 40, 2009, p. 1747.

32.ROJ ANAPITAYAKORN P., MATHER P.T., GOLDBERG A.J ., WEISS R.A. Polymer 2005;46:761-73.

33.DUHOVIC, M., BHATTACHARYYA, D., FAKIROV, S., Macromol Mater Eng., 295, 2010, p. 95.

34.CHEN, J.C., WU, C.M., PU F. C., CHIU C. H.: eXPRESS Polymer Letters, 5, no. 3, 2011, p. 228

35.FRYCZ, W, KRYWULT B., Design and manufacture of plastic components, Rzeszow, Rzeszow University of Technology Publishing House, 2005.

27. SIKORA, R., Processing of high-molecular plastics, Warsaw, 'ak, 1993

28. KOSZKULA, J., BOCIYGI E., (editors), Polymer materials and their processing, Czestochowa University of Technology Publishing House, 2004.

29. GADEK A., KUCIEL S., WOJ NAR L., DZIADUR W, Polimery, 51, 3, 2006, p. 206.

30. GADEK-MOSZCZAK A., ZMUDKA, S., Solid State Phenomena, 197, 2013, p. 186.

Manuscript received: 21.09 .2018 